\title{
Haematozoans from deep water fishes trawled off the Cape Verde Islands and over the Porcupine Seabight, with a revision of species within the genus Desseria (Adeleorina: Haemogregarinidae)
}

\author{
Angela J. Davies ${ }^{1}$, Shazia Hosein ${ }^{1,2}$ and Nigel R. Merrett ${ }^{3,4}$ \\ ${ }^{1}$ School of Life Sciences, Faculty of Science, Kingston University, Penrhyn Road, Kingston upon Thames, Surrey KT1 2EE, UK; \\ ${ }^{2}$ The Royal Veterinary College, Hawkshead Lane, North Mymms, Hertfordshire AL9 7TA, UK; \\ ${ }^{3}$ Muttlebury's Mead, Chard Street, Thorncombe, Dorset TA20 4NB, UK; \\ ${ }^{4}$ Formerly at: Department of Zoology, The Natural History Museum, Cromwell Road, London SW7 5BD, UK
}

\begin{abstract}
Archived blood smears from 32 of 113 fishes in 18 families and 12 orders, trawled from deep North Atlantic waters off the Cape Verde Islands in 1999 and over the Porcupine Seabight in 2001 were found to harbour haematozoans. These included four species of haemogregarines (Adeleorina, Haemogregarinidae) and a species of trypanosome (Trypanosomatina, Trypanosomatidae) located in Porcupine Seabight fishes. Also present were Haemohormidium-like structures of uncertain status found in samples from this location and from the Cape Verde Islands. Although material was limited, two of the haemogregarines were provisionally named Desseria harriottae sp. n. from Harriotta raleighana Goode et Bean (Chimaeriformes, Rhinochimaeridae), and Haemogregarina bathysauri sp. n. from Bathysaurus ferox Günther (Aulopiformes, Bathysauridae). The two remaining haemogregarines were identified as Desseria marshalllairdi (Khan, Threlfall et Whitty, 1992) from Halosauropsis macrochir (Günther) (Notacanthiformes, Halosauridae), and Haemogregarina michaeljohnstoni (Davies et Merrett, 2000) from Cataetyx laticeps Koefoed (Ophidiformes, Bythitidae). The name H. michaeljohnstoni was proposed to replace Haemogregarina johnstoni Davies et Merrett, 2000 from C. laticeps and to avoid confusion with Hepatozoon johnstoni (Mackerras, 1961) Smith, 1996 from varanid lizards, originally named Haemogregarina johnstoni Mackerras, 1961. The trypanosome formed a mixed parasitaemia with D. harriottae in H. raleighana and was provisionally named Trypanosoma harriottae sp. n. No blood parasites had been described previously from cartilaginous fishes of the Holocephali, making the finds in H. raleighana unique. Haemohormidium-like structures were located in erythrocytes in one fish, Coryphaenoides armatus (Hector), among the Cape Verde Islands samples and in 12 species of fishes from the Porcupine Seabight; all these hosts were bony fishes. Finally, the haemogregarine species listed in the genus Desseria Siddall, 1995 were reassessed. Of the original list of 41 species, 30 were retained and 5 species added, including $D$. harriottae, so that the genus now contains 35 species.
\end{abstract}

Keywords: deep sea haematozoans, haemogregarines, Desseria, Haemogregarina, trypanosomes, Trypanosoma, Haemohormidium

Khan et al. (1992), Davies and Merrett (1998, 2000), and Smit and Davies (2006) all recorded haematozoans from fishes inhabiting deep marine waters. Trawl depths were between $1000-3200 \mathrm{~m}$ in the Northwest Atlantic (Khan et al. 1992), between $747-4875 \mathrm{~m}$ in the Northeast Atlantic (Davies and Merrett 1998, 2000), down to $202 \mathrm{~m}$ in the Indian Ocean and to $389 \mathrm{~m}$ in the Southern Atlantic (Smit and Davies 2006). Blood films from the trawled fishes in three of these studies revealed protistan parasites. They included: haemogregarines (Apicomplexa, Eucoccidiorida, Adeleorina), trypanosomes (Euglenozoa, Kinetoplastea, Trypanosomatina) and cryptobiids (Euglenozoa, Kinetoplastea, Bodonina) from the Northwest Atlantic adjacent to Carson Canyon and the New York Bight (Khan et al. 1992); haemogregarines from the Northeast Atlantic in the vicinity of the Porcupine Seabight (Davies and Merrett 2000); and a haemogregarine in the Indian Ocean and Southern Atlantic, off South Africa (Smit and Davies 2006). Haemohormidium-like structures of uncertain identity were recorded only in North Atlantic blood samples (Khan et al. 1992, Davies and Merrett 2000), and presumptive viral erythrocytic necrosis (VEN) in fishes from the Northeast Atlantic, off Portugal (Davies and Merrett 1998) and from the Porcupine Seabight (Davies and Merrett 2000).

Archived blood films have been studied from two further deep sea trawls. The first originated in the vicinity of the Cape Verde Islands, off West Africa, and the second was another trawl from the Porcupine Seabight, southwest of Ireland, both sites lying in the Northeast Atlantic Ocean. This paper records the haemogregarines, trypanosomes and Haemohormidium-like structures observed 
in the blood films, and it includes descriptions of new protistan species. In addition, species listed within the haemogregarine genus Desseria Siddall, 1995 are revised, as well as the name of a haemogregarine within the genus Haemogregarina Danilewsky, 1885.

\section{MATERIALS AND METHODS}

Twenty eight fishes of 11 species were sampled from trawls off the Cape Verde Islands at depths of 50-800 m in mid-water and $3212-4062 \mathrm{~m}$ on the bottom, during the Discovery 243 cruise of October, 1999. A further 85 fishes of 28 species, were sampled from trawls in the Porcupine Seabight in soundings of 772-3718 m during the Discovery 252 cruise of April, 2001. Fishes were caught in mid-water using a rectangular mid-water trawl and on the bottom with a semi-balloon otter trawl, and were identified on deck by one of us (NRM). As previously (Davies and Merrett 1998, 2000), fish length was measured according to common convention for each species (see Table 1) and blood smears (one per fish) taken from the caudal vein or heart were stored in a waterproof container and archived.

Blood smears were subsequently fixed in absolute methanol and stained with standard phosphate buffered Giemsa ( $\mathrm{pH}$ 6.8) They were screened for at least 30 minutes each with the $\times 100$ oil-immersion objective lens of a Nikon Eclipse 80i microscope. Images were captured by digital camera (Nikon DS-5M) and measured with a Nikon NIS 2.10 image analysis system, calibrated to a stage micrometer; where appropriate, means were calculated \pm standard deviation using Microsoft Excel software within the Nikon NIS 2.10 system. All slides from the current work and those from earlier deep sea sampling (Davies and Merrett 1998, 2000) were deposited in the Protistology Section, The Natural History Museum, Cromwell Road, London SW7 5BD, UK. New species were designated specific registration numbers, whereas known species within trawls were lodged as voucher specimens (see Results).

\section{RESULTS}

\section{General observations}

The 113 fishes of 35 species captured off the Cape Verde Islands and in the vicinity of the Porcupine Seabight are recorded in Table 1. Both cartilaginous (Chondrichthyes) and bony (Osteichthyes) fishes were represented in trawls, although only two species of cartilaginous fishes were examined, one from a family and order in each of the Elasmobranchii and the Holocephali (Table 1). The remaining samples were from rayfinned, bony fishes (Actinopterygii, Teleostei) belonging to 16 families in 10 orders (Table 1).

As in previous studies from the Northeast Atlantic (Davies and Merrett 1998, 2000), most blood smears were in remarkably good condition considering the depths from which the fishes had been raised, as well as the time over which smears had been archived. Screening of stained smears revealed haemogregarines, trypanosomes and Haemohormidium-like structures (Figs. 1A-N, 2A-P), but cryptobiids and presumptive VEN were not detected. Haemogregarines and trypanosomes were found only in Porcupine Seabight material. The former occurred in both cartilaginous (Harriotta raleighana Goode et Bean) and bony fishes (Bathysaurus ferox Günther, Halosauropsis macrochir (Günther), and Cataetyx laticeps Koefoed) (Table 1, Figs. 1A-L, 2A-F,H-P), but trypanosomes only in a cartilaginous fish (H. raleighana) (Table 1, Fig. 1M,N). Haemohormidium-like structures were seen in both Cape Verde (one fish, Coryphaenoides armatus (Hector), taken from a bottom trawl) and Porcupine Seabight samples (fishes of 12 species), but only in bony fishes (Table 1). Except for Haemohormidium (Fig. 2G), to which no useful description could be added beyond that reported previously in Porcupine Seabight material (Davies and Merrett 2000), the protists observed are described below. Parasitaemias were consistently low across all infected fishes, being from $\sim 0.01 \%$ to $<0.001 \%$ of erythrocytes for both haemogregarines and Haemohormidium. A single blood film from $H$. raleighana containing trypanosomes (see below) had 11 such measureable organisms.

\section{Description of the haematozoans}

Phylum Apicomplexa Levine, 1980

Class Conoidasida Levine, 1988

Order Eucoccidiorida Léger et Duboscq, 1910

Suborder Adeleorina Léger, 1911

Family Haemogregarinidae Léger, 1911

\section{Genus Desseria Siddall, 1995}

\section{Desseria harriottae sp. $\mathrm{n}$.}

Stages in the blood of Harriotta raleighana Goode et Bean

Pregamonts. Small, intraerythrocytic stages (Fig. $1 \mathrm{~A}-\mathrm{D}), 8.7 \pm 0.8 \mu \mathrm{m}(7.5-9.9 \mu \mathrm{m})$ by $2.5 \pm 0.2 \mu \mathrm{m}(2.0$ $-2.8 \mu \mathrm{m})(\mathrm{n}=9)$, but rarely extracellular, these 8.4 by $2.2 \mu \mathrm{m}, 9.7$ by $2.6 \mu \mathrm{m}$ respectively $(\mathrm{n}=2)$; occurring singly when intraerythrocytic. Similar to broad forms (below), but slender. Straight or slightly curved, with rounded anterior extremity, bluntly pointed posterior pole. Cytoplasm blue-stained, finely granular, sometimes with larger dark blue-stained granules, particularly at posterior pole of parasite body (Fig. 1A,C). Single nucleus centrally located within parasite body (Fig. 1A,B), $2.0 \pm 0.2 \mu \mathrm{m}$ $(1.8-2.3 \mu \mathrm{m})$ by $1.4 \pm 0.2 \mu \mathrm{m}(1.1-1.7 \mu \mathrm{m})(\mathrm{n}=9)$.

Gamonts. Intraerythrocytic (Fig. 1E,F,H,J,K), 8.7 $\pm 0.7 \mu \mathrm{m}(7.4-9.6 \mu \mathrm{m})$ by $3.2 \pm 0.3 \mu \mathrm{m}(2.7-3.5 \mu \mathrm{m})$ $(\mathrm{n}=8)$, but rarely extracellular (Fig. 1G,I,L), these 9.0 by $3.5 \mu \mathrm{m}, 9.1$ by $3.6 \mu \mathrm{m}, 9.7$ by $3.8 \mu \mathrm{m}$ respectively $(\mathrm{n}=3)$; occurring singly when intraerythrocytic. Broad stages, often slightly curved, or club-shaped (Fig. 1H,I); rounded anterior pole, posterior extremity usually tapering to a blunt point. Cytoplasm generally blue-stained, lightly stippled or finely granular, sometimes with a small deepstained anterior cap and three prominent granules anterior to nucleus (Fig. 1L), posterior region often stained deep blue with large granule at posterior extremity (Fig. 1H,I,J). Nucleus not always clearly visible, generally centrally 
Table 1. Taxonomic grouping, identity and numbers of fishes trawled off the Cape Verde Islands and over the Porcupine Seabight; fish length as, GNPL: gnathoproctal length, HL: head length, SL: standard length, TL: total length; broad parasite identity, Hg: haemogregarine, Hm: Haemohormidium-like infection, T: trypanosome; where appropriate, left hand figures in column 5 refer to Cape Verde, right hand figures to the Porcupine Seabight; figures in column 6 refer to depths at, or between which, fishes were trawled.

\begin{tabular}{|c|c|c|c|c|c|}
\hline $\begin{array}{l}\text { Fishes species captured by taxonomic } \\
\text { grouping }\end{array}$ & $\begin{array}{c}\text { Number } \\
\text { Cape Verde }\end{array}$ & $\begin{array}{l}\text { Number Porcu- } \\
\text { pine Seabight }\end{array}$ & $\begin{array}{l}\text { Type of length } \\
\text { measurement in } \mathrm{mm}\end{array}$ & $\begin{array}{c}\text { Number parasitized } \\
\text { (broad parasite identity) }\end{array}$ & $\begin{array}{l}\text { Trawl depth } \\
\text { in } \mathrm{m}\end{array}$ \\
\hline \multicolumn{6}{|l|}{ CHONDRICHTHYES: Elasmobranchii } \\
\hline \multicolumn{6}{|l|}{ Rajiformes: Rajidae } \\
\hline Bathyraja abyssicola (Gilbert) & & 1 & $520 \mathrm{SL}$ & $0 / 1$ & $2398-2470$ \\
\hline \multicolumn{6}{|l|}{ CHONDRICHTHYES: Holocephali } \\
\hline \multicolumn{6}{|l|}{ Chimaeriformes: Rhinochimaeridae } \\
\hline Harriotta raleighana Goode et Bean & & 1 & $810 \mathrm{TL}$ & $1 / 1(\mathrm{Hg}, \mathrm{T})$ & $1631-1653$ \\
\hline \multicolumn{6}{|l|}{$\begin{array}{l}\text { OSTEICHTHYES: Actinopterygii: Teleostei } \\
\text { Anguilliformes: Synaphobranchidae }\end{array}$} \\
\hline Histiobranchus bathybius (Günther) & 3 & 3 & $750-825 \mathrm{SL}$ & $0 / 3,1 / 3(\mathrm{Hm})$ & $4031-4052$ \\
\hline Synaphobranchus kaupii Johnson & & 6 & $410-735 \mathrm{SL}$ & $0 / 6$ & $2274-2300$ \\
\hline \multicolumn{6}{|l|}{ Aulopiformes: Alepisauridae } \\
\hline Alepisaurus ferox Lowe & 1 & & & $0 / 1$ & 800 \\
\hline \multicolumn{6}{|l|}{ Aulopiformes: Bathysauridae } \\
\hline Bathysaurus ferox Günther & & 2 & $520,565 \mathrm{HL}$ & $1 / 2(\mathrm{Hg}, \mathrm{Hm})$ & $1631-1653$ \\
\hline Bathysaurus mollis Günther & 2 & & & $0 / 2$ & $4031-4052$ \\
\hline \multicolumn{6}{|l|}{ Aulopiformes: Ipnopidae } \\
\hline Bathypterois dubius Vaillant & & 1 & $175 \mathrm{SL}$ & $0 / 1$ & $1175-1250$ \\
\hline Bathypterois grallator (Goode et Bean) & 1 & & & $0 / 1$ & 3212 \\
\hline \multicolumn{6}{|l|}{ Gadiformes: Macrouridae } \\
\hline Coryphaenoides armatus (Hector) & 8 & 10 & 92-143 HL & $1 / 8,4 / 10(\mathrm{Hm})$ & $4031-4062$ \\
\hline Coryphaenoides guentheri (Vaillant) & & 5 & 60-73 HL & $2 / 5(\mathrm{Hm})$ & $2274-2300$ \\
\hline Coryphaenoides leptolepis Günther & & 2 & $74,95 \mathrm{HL}$ & $0 / 2$ & $2560-3718$ \\
\hline Coryphaenoides mediterraneus (Giglioli) & & 3 & 95-96 HL & 2/3 (Hm) & $1631-1653$ \\
\hline Coryphaenoides profundicolus (Nybelin) & 3 & 3 & $136-182 \mathrm{HL}$ & $0 / 3,0 / 3$ & $4031-4052$ \\
\hline Coryphaenoides rupestris Gunnerus & & 6 & 97-151 HL & $3 / 6(\mathrm{Hm})$ & 1500 \\
\hline Nezumia aequalis (Günther) & & 4 & 45-51 HL & $2 / 4(\mathrm{Hm})$ & $772-845$ \\
\hline Trachyrincus scabrus (Rafinesque) & & 4 & $118-148 \mathrm{HL}$ & $0 / 4$ & $1175-1250$ \\
\hline \multicolumn{6}{|l|}{ Gadiformes: Moridae } \\
\hline Antimora rostrata (Günther) & & 5 & $402-560 \mathrm{SL}$ & $2 / 5(\mathrm{Hm})$ & $2274-2300$ \\
\hline Halargyreus johnsonii Günther & & 3 & $303-343 \mathrm{SL}$ & $0 / 3$ & $1175-1250$ \\
\hline Lepidion eques (Günther) & & 6 & $262-303 \mathrm{SL}$ & $0 / 6$ & $1175-1250$ \\
\hline Mora mora (Risso) & & 2 & $450,600 \mathrm{SL}$ & $2 / 2(\mathrm{Hm})$ & 1053-1077 \\
\hline \multicolumn{6}{|l|}{ Notacanthiformes: Halosauridae } \\
\hline Halosauropsis macrochir (Günther) & & 3 & 201-239 GNPL & $3 / 3(\mathrm{Hg}, \mathrm{Hm})$ & $2274-2300$ \\
\hline \multicolumn{6}{|l|}{ Notacanthiformes: Notacanthidae } \\
\hline Notacanthus chemnitzii Bloch & & 1 & $760 \mathrm{SL}$ & $0 / 1$ & $2400-2500$ \\
\hline \multicolumn{6}{|l|}{ Ophidiformes: Bythitidae } \\
\hline Cataetyx laticeps Koefoed & & 3 & 315-806 SL & $3 / 3(\mathrm{Hg})$ & $1631-1653$ \\
\hline \multicolumn{6}{|l|}{ Ophidiiformes: Ophidiidae } \\
\hline Spectrunculus grandis (Günther) & & 1 & $440 \mathrm{SL}$ & $0 / 1$ & $2398-2470$ \\
\hline \multicolumn{6}{|l|}{ Perciformes: Aphanopodinae } \\
\hline Aphanopus carbo Lowe & & 5 & $832-1110 \mathrm{SL}$ & 4/5 (Hm) & $1175-1250$ \\
\hline \multicolumn{6}{|l|}{ Salmoniformes: Alepocephalidae } \\
\hline Alepocephalus bairdii Goode et Bean & & 1 & $570 \mathrm{HL}$ & $1 / 1(\mathrm{Hm})$ & 1500 \\
\hline Conocara salmonea (Gill et Townsend) & 2 & 1 & $650 \mathrm{SL}$ & $0 / 2,0 / 1$ & $4031-4052$ \\
\hline Narcetes stomias (Gilbert) & & 1 & $480 \mathrm{SL}$ & $0 / 1$ & $772-845$ \\
\hline \multicolumn{6}{|l|}{ Scorpaeniformes: Psychrolutidae } \\
\hline Cottunculus thomsonii (Günther) & & 1 & $310 \mathrm{HL}$ & $0 / 1$ & $1175-1250$ \\
\hline \multicolumn{6}{|l|}{ Stomiiformes: Gonostomatidae } \\
\hline Gonostoma elongatum Günther & 3 & & & $0 / 3$ & $220-302$ \\
\hline Stomiiformes: Stomiidae & & & & & \\
\hline Borostomias elucens (Brauer) & 1 & & & $0 / 1$ & 603 \\
\hline Chauliodus sloani Bloch et Schneider & 1 & & & $0 / 1$ & 4046 \\
\hline Stomias boa boa (Risso) & 3 & & & $0 / 3$ & $50-300$ \\
\hline Zoarciformes: Zoarcidae & & & & & \\
\hline Pachycara crassiceps (Roule) & & 1 & $483 \mathrm{SL}$ & $0 / 1$ & $1631-1653$ \\
\hline TOTAL & 28 & 85 & - & $1 / 28 ; 31 / 85$ & - \\
\hline
\end{tabular}




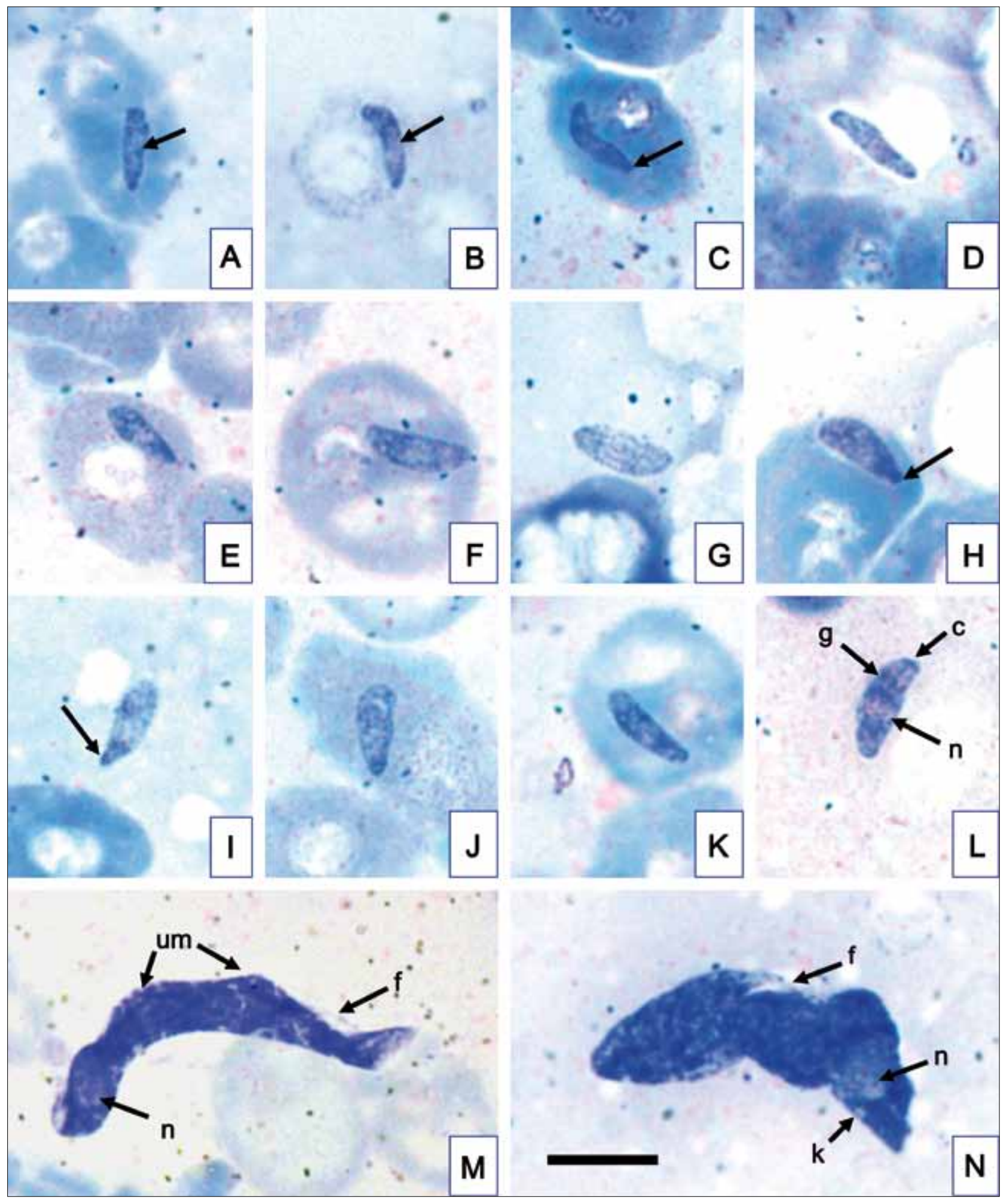

Fig. 1. Giemsa-stained blood film from Harriotta raleighana with Desseria harriottae sp. n. (A-L) and Trypanosoma harriottae sp. n. (M, N). A-D - slender pregamonts. Note nucleus (arrows in A, B) and terminal granule (arrow in C). D - extracellular slender form. $\mathbf{E}-\mathbf{L}$ - broader gamonts. Note some are club-shaped (E, H, I), others have terminal granules (arrows in H, I). $\mathbf{L}$ - extracellular form with anterior cap (c), three granules (g) anterior to the nucleus (n). $\mathbf{M}, \mathbf{N}$ - trypomastigotes showing nucleus (n), undulating membrane (um), flagellum (f) and kinetoplast (k). Note the granular cytoplasm. Scale bar A-N $=10 \mu \mathrm{m}$. 


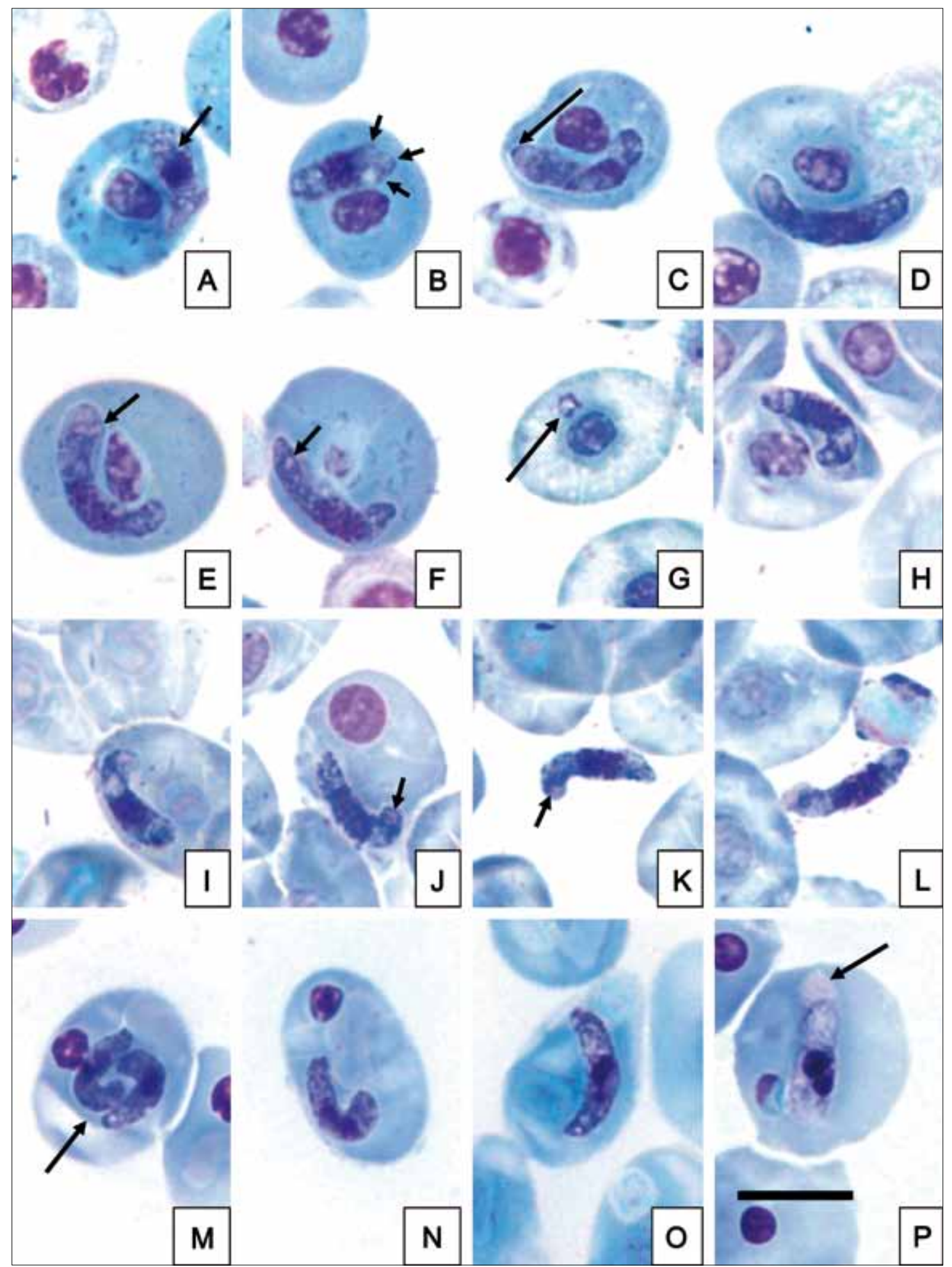

Fig. 2. Giemsa-stained blood films from Bathysaurus ferox with Haemogregarina bathysauri sp. n. (A-F), from Halosauropsis macrochir with Haemohormidium (G) and Desseria marshallairdi $(\mathrm{H}-\mathrm{L})$, and from Cataetyx laticeps with Haemogregarina michaeljohnstoni (syn. H. johnstoni) (M-P). A, B - possible meronts. Note that meront body appears either undivided (arrow in A), or to comprise a bundle of three individuals (arrows in B). C - curved gamont showing small cap (arrowed) at broad anterior extremity. D-F - further examples of gamonts. Note some show vacuolation (arrows in E, F), one has a more reflexed posterior extremity (F). $\mathbf{G}$ - arrow points to typical Haemohormidium-like structure. $\mathbf{H}, \mathbf{I}$ - intraerythrocytic gamonts with reflexed posterior extremities. $\mathbf{J}-\mathbf{L}$ - extracellular gamonts retaining hooked posterior. Note vacuoles near posterior extremity (arrows in J, K). M, N-paired (arrow, $\mathrm{M}$ ) or single $(\mathrm{N})$ intraerythrocytic merozoites or pregamonts. $\mathbf{O}$ - large, slender, granular gamont. $\mathbf{P}$ - large, pale gamont. Note the striped cap region (arrow). Scale bar $\mathrm{A}-\mathrm{P}=10 \mu \mathrm{m}$. 
positioned, or slightly anterior, pale pink-stained (Fig. 1L); nucleus $2.4 \pm 0.3 \mu \mathrm{m}(2.1-3.2 \mu \mathrm{m})$ by $1.9 \pm 0.4 \mu \mathrm{m}$ $(1.5-2.9 \mu \mathrm{m})(\mathrm{n}=8)$.

Forming a mixed infection with a trypanosome (see below).

Type host: Harriotta raleighana Goode et Bean (Holocephali, Chimaeriformes, Rhinochimaeridae).

Type locality: Porcupine Seabight, Northeast Atlantic $49^{\circ} 49.9^{\prime} \mathrm{N}, 12^{\circ} 10.8^{\prime} \mathrm{W}$ (depth from $1631 \mathrm{~m}$ ).

Site of infection: Erythrocytes of $H$. raleighana and extracellularly.

Prevalence: $1 / 1$ H. raleighana.

Specimen deposited: Hapantotype slide: in the collection of the Natural History Museum, London, UK (fish blood film with pregamonts and gamonts of D. harriottae, Registration Number NHMUK 2011.7.16.1).

Etymology: The species epithet refers to the host genus.

Remarks. Only two stages of development were observed in this small haemogregarine, provisionally identified as slender pregamonts and broader gamonts. Furthermore, no evidence of intraerythrocytic division was detected, which places it in the interim within the genus Desseria Siddall, 1995 (see Siddall 1995). Until more parasitized specimens of this unusual fish are located, it is impossible to determine whether further stages of the haemogregarine exist in blood. However, we are unaware of any blood parasite having been described from cartilaginous fishes within the entire subclass Holocephali, a feature emphasised by Davies and Johnston (2000). Thus, because of the unique nature of this find in deep sea material and the perceived absence of division in erythrocytes, the parasite is provisionally named Desseria harriottae $\mathrm{sp} . \mathrm{n}$.

Desseria marshallairdi (Khan, Threlfall et Whitty, 1992) Smith, 1996

Stages in the blood of Halosauropsis macrochir (Günther)

Gamonts. Intraerythrocytic (Fig. 2H,I) $12.9 \pm 0.9 \mu \mathrm{m}$ $(10.1-14.9 \mu \mathrm{m})$ by $3.3 \pm 0.3 \mu \mathrm{m}(3.0-3.9 \mu \mathrm{m})(\mathrm{n}=25)$, and extracellular forms (Fig. 2J-L), $13.6 \pm 0.9 \mu \mathrm{m}(12.1-$ $15.8 \mu \mathrm{m})$ by $3.2 \pm 0.4 \mu \mathrm{m}(2.5-4.2 \mu \mathrm{m})(\mathrm{n}=20)$, occurring singly when intraerythrocytic. Hook-like in outline, straight bodied with broadly pointed or rounded anterior pole and reflexed posterior end (Fig. 2H-L). Cytoplasm generally stained deep blue with fine stippling and some granulation, no anterior cap observed, but pink-stained vacuoles in the posterior, reflexed region of the parasite body (Fig. 2J-L). Nucleus prominent, generally centrally placed or slightly anterior to mid-point of parasite body, chromatin coarse, deep blue-stained (Fig. 2H-L); nucleus $3.5 \pm 0.6 \mu \mathrm{m}(2.6-6.1 \mu \mathrm{m})$ by $2.4 \pm 0.4 \mu \mathrm{m}(1.8-3.0 \mu \mathrm{m})$ $(\mathrm{n}=25)$.

Remarks. Khan et al. (1992) recorded a haemogregarine from 1/6 Halosauropsis macrochir from the New York Bight, but this organism was not illustrated or identi- fied. The authors (Khan et al. 1992) also described Desseria marshalllairdi (syn. Haemogregarina marshalllairdi) from Macrourus berglax Lacépède and Nezumia bairdi (Goode et Bean), from the New York Bight and Carson Canyon, both fishes being members of the Macrouridae. Although no haemogregarines were detected in fishes of this family in the present study, the organisms discovered in H. macrochir appear to lack division stages, and intracellular gamonts resemble $D$. marshalllairdi in length (11.8 $\mu \mathrm{m}$, according to Khan et al. 1992) and are only slightly wider (D. marshalllairdi is $2.5 \mu \mathrm{m}$ wide). Their overall appearance, particularly the tendency for the posterior end to be reflexed and the nucleus to lie centrally, is also close to D. marshalllairdi. Cytoplasm is perhaps more granular in the present specimens and nuclear chromatin coarser, but these differences could result from differing staining responses. Since the haemogregarine found in $3 / 3 H$. macrochir does not closely resemble any other found in marine fishes (see Davies 1995), it is concluded that the specimens captured over the Porcupine Seabight are D. marshalllairdi, despite occurring in a different taxonomic group of bony fishes (Notacanthiformes, Halosauridae) from the type species. Voucher specimens of this organism are lodged with The Natural History Museum, London.

\section{Genus Haemogregarina Danilewsky, 1885}

\section{Haemogregarina (sensu lato) bathysauri sp. $\mathrm{n}$.}

Stages in the blood of Bathysaurus ferox Günther

Meronts? Intraerythrocytic, short, broad stages (Fig. $2 \mathrm{~A}, \mathrm{~B}), \quad 10.3 \pm 1.0 \mu \mathrm{m}(8.4-11.2 \mu \mathrm{m})$ by $3.7 \pm 0.3 \mu \mathrm{m}$ $(3.1-4.0 \mu \mathrm{m})(\mathrm{n}=5)$, once appearing to comprise a bundle of three individuals (Fig. 2B), each 7.2-8.0 $\mu \mathrm{m}$ long by $1.2-1.6 \mu \mathrm{m}$ long $(\mathrm{n}=3)$. Broad stages overall, occasionally slightly curved, with rounded poles. Cytoplasm generally deep blue-stained, finely stippled, or finely granular and slightly vacuolated. Nucleus prominent and deep-stained purple, with coarse chromatin; nucleus generally centrally positioned in parasite body, $3.3 \pm 0.3 \mu \mathrm{m}$ $(2.7-3.6 \mu \mathrm{m})$ by $2.8 \pm 0.5 \mu \mathrm{m}(2.0-3.2 \mu \mathrm{m})(\mathrm{n}=5)$.

Gamonts. Intraerythrocytic, long, curved stages (Fig. $2 \mathrm{C}-\mathrm{F}), 15.8 \pm 1.5 \mu \mathrm{m}(13.8-17.6 \mu \mathrm{m})$ by $3.6 \pm 0.4 \mu \mathrm{m}$ $(3.3-4.3 \mu \mathrm{m})(\mathrm{n}=5)$; rounded, broad anterior extremity, tapering posteriorly, with rounded posterior pole, once observed to be reflexed posteriorly (Fig. 2F). Cytoplasm generally deep blue stained, lightly stippled or granular, anterior pole with small, dense cap in some individuals (Fig. 2C), sometimes with prominent vacuoles present, especially anterior to the nucleus (Fig. 2E,F). Nucleus positioned centrally or towards posterior pole, deep pink or purple stained, with coarse chromatin; nucleus $4.5 \pm 1.3 \mu \mathrm{m}(2.2-5.9 \mu \mathrm{m})$ by $2.4 \pm 0.5 \mu \mathrm{m}(1.6-2.8 \mu \mathrm{m})$ $(\mathrm{n}=5)$.

Type host: Bathysaurus ferox Günther (Teleostei, Aulopiformes, Bathysauridae). 
Type locality: Porcupine Seabight, Northeast Atlantic $49^{\circ} 49.9^{\prime} \mathrm{N}, 12^{\circ} 10.8^{\prime} \mathrm{W}$ (depth from $1631 \mathrm{~m}$ ).

Site of infection: Erythrocytes of $B$. ferox.

Prevalence: $1 / 2$ B. ferox.

Specimen deposited: Hapantotype slide: in the collection of the Natural History Museum, London, UK (fish blood film with possible meronts, and gamonts of $H$. bathysauri, Registration Number NHMUK 2011.7.16.2).

Ety m ology: The species epithet refers to the host genus.

Remarks. Khan et al. (1992) also recorded a haemogregarine in 1/8 Bathysaurus ferox from the New York Bight, although it was not illustrated or described by the authors. In the current study, broad stages, as well as more slender individuals, which were clearly gamonts, were found in $1 / 2$ B. ferox. One example of a broad stage appeared to comprise a tight bundle of three individuals, and for this reason it is tentatively identified as a meront. If intraerythrocytic division does occur, then this has taxonomic implications because haemogregarines of marine fishes demonstrating this feature are currently members of the genus Haemogregarina Danilewsky, 1885 sensu lato (see Siddall 1995).

Although gamonts of this haemogregarine broadly resemble those of Desseria marshalllairdi in general appearance, current specimens are much longer and wider (up to 17.6 by $4.3 \mu \mathrm{m}$ ) than those of Khan et al. (1992) which were 11.8 by $2.5 \mu \mathrm{m}$. Khan et al. (1992) also described, but did not name (beyond Haemogregarina spp.) a further two haemogregarines from deep sea fishes. One in Lycodonus mirabilis Goode et Bean measured 18 by $5.1 \mu \mathrm{m}$ and was elongate to reniform in appearance, with light blue stained cytoplasm, vacuoles at one pole, and a centrally placed nucleus; it also displaced and compressed the host cell nucleus. The other haemogregarine, in Synaphobranchus affinis Günther, was 16.5 by $3.8 \mu \mathrm{m}$, of similar overall morphology, but had granular, alveolar cytoplasm, a subterminal or centrally located nucleus, and lacked a polar cap; host cell nuclei were occasionally hypertrophied and cells enlarged.

Gamonts of the current haemogregarine are clearly intermediate in size between the two Haemogregarina spp. of Khan et al. (1992). They also have, in some cases, a small stained anterior cap, a nucleus positioned towards the posterior end of the parasite body, prominent cytoplasmic vacuoles anterior to the nucleus, a broad anterior, and a generally curved body shape, and no adverse effects on host cells were noted. Overall, these features are not characteristic of D. marshallairdi, or the two Haemogregarina spp. of Khan et al. (see above), and the parasite does not closely resemble any other haemogregarine found in marine fishes. It is unsatisfactory to name a new species based on a few specimens recorded from just one slide, but because of its possible meront, its size, other morphological features, and the unusual nature of this deep sea find, the haemogregarine found in B. ferox is, in the interim, named Haemogregarina sensu lato bathysauri sp. n., until further specimens of this parasite can be examined.

\section{Haemogregarina sensu lato johnstoni Davies et} Merrett, 2000

Stages in the blood of Cataetyx laticeps Koefoed

Merozoites or pregamonts. Short, strongly curved stages, in pairs or singly within erythrocytes (Fig. 2M,N), $11.3-13.1$ by $2.9-3.4 \mu \mathrm{m}(\mathrm{n}=3)$; one extremity (anterior?) slightly broader and more rounded than the other. Cytoplasm deep blue-stained and finely granular. Nucleus deep blue to purple-stained, generally centrally placed within parasite body; nuclei $2.8-4.2$ by $1.9-2.1 \mu \mathrm{m}$ $(\mathrm{n}=3)$.

Gamonts. Of two discernible types (Fig. 2O,P). Long, slender, slightly curved gamonts (Fig. 2O), 13.8-16.7 by $3.2-3.3 \mu \mathrm{m}(\mathrm{n}=3)$; anterior slightly broader than posterior; cytoplasm deep blue-stained, especially posteriorly, cytoplasm also granular and vacuolated especially posteriorly (Fig. 2O); nucleus deep blue-stained and centrally placed; nuclei $3.1-3.8$ by $1.9-2.6 \mu \mathrm{m}(\mathrm{n}=3)$. Broad, pale, gamonts (Fig. 2P), 12.3-13.2 by $4.0-4.6 \mu \mathrm{m}(\mathrm{n}=3)$; anterior slightly broader than posterior; cytoplasm pale blue-stained, with a large anterior striped cap; nucleus deep blue-stained, lying in posterior half of parasite body; nuclei $4.0-4.4$ by $2.9-3.2 \mu \mathrm{m}(\mathrm{n}=3)$.

Remarks. Haemogregarina johnstoni Davies et Merrett, 2000 was reported from a single specimen of the same host, Cataetyx laticeps, also from the Porcupine Seabight (Davies and Merrett 2000). At that time the authors observed evidence of pregamontic fission, and the paired, intraerythrocytic immature forms in the current samples, identified as merozoites or pregamonts, may have resulted from such division. Larger, granular gamonts, as well as pale gamonts with pronounced striped caps were also identified in both studies. Davies and Merrett (2000) were uncertain whether the granular and pale gamonts represented two species of haemogregarine, growth stages of the same form, or sexual dimorphism (male and female gamonts) within a single species. The authors concluded that the haemogregarine stages belonged to the same species (Davies and Merrett 2000), which is supported by the current observation of both these gamont forms in $3 / 3$ C. laticeps from the Porcupine Seabight. However, as in the previous study (Davies and Merrett 2000), no developmental stages intermediate between the granular and the pale gamonts were observed, so the questions whether they are growth stages of each other, or represent gamonts showing sexual dimorphism remain unresolved.

In 1961, Mackerras (1961) named Haemogregarina johnstoni, a haemogregarine of lizards Varanus spp. and subsequently, Smith (1996) renamed this species Hepatozoon johnstoni (Mackerras, 1961). Hepatozoon johnstoni (Mackerras, 1961) Smith, 1996 was clearly distinct from 
Haemogregarina johnstoni Davies et Merrett, 2000 at the time of naming the latter species. However, to avoid possible future confusion between the two species, the following nomenclatural modification is recommended: Haemogregarina sensu lato michaeljohnstoni (Davies et Merrett, 2000) (syn. Haemogregarina johnstoni Davies et Merrett, 2000) in Cataetyx laticeps Koefoed (Osteichthyes, Bythitidae) erythrocytes. The species epithet remains as a tribute to the work of Dr. Michael R.L. Johnston. The original type specimen (see Davies and Merrett 2000) and voucher specimens of this organism are lodged with The Natural History Museum, London.

Phylum Euglenozoa Cavalier-Smith, 1981

Class Euglenoidea Bütschli, 1884

Order Kinetoplastea Honigberg, 1963

Suborder Trypanosomatina Kent, 1880

Family Trypanosomatidae Doflein, 1901

\section{Genus Trypanosoma Gruby, 1843}

\section{Trypanosoma harriottae sp. $\mathrm{n}$.}

Stages in the blood of Harriotta raleighana Goode et Bean

Trypomastigotes. Polymorphic, but generally large organisms, with rounded or broadly pointed extremities, and highly granular, deep blue-stained cytoplasm (Fig. $1 \mathrm{M}, \mathrm{N})$; total body length $29.9 \pm 3.8 \mu \mathrm{m}(24.1-38.4 \mu \mathrm{m})$, body width $7.4 \pm 1.7 \mu \mathrm{m}(5.5-12.0 \mu \mathrm{m})(\mathrm{n}=11)$. Free flagellum short, staining poorly, often obscured by parasite body, but $\sim 10 \mu \mathrm{m}$ long. Undulating membrane shallow, often difficult to discern, with 3-5 undulations. Kinetoplast also difficult to detect, situated close to nucleus, $\sim 4-5 \mu \mathrm{m}$ from posterior extremity. Nucleus rounded to oval, pale pink-stained, often obscured by granulation of parasite cytoplasm, nuclear length $4.6 \pm 0.5 \mu \mathrm{m}(4.0-5.6 \mu \mathrm{m})$, nuclear width $3.7 \pm 0.7 \mu \mathrm{m}$ $(2.9-5.1 \mu \mathrm{m})(\mathrm{n}=11)$; nucleus usually situated towards posterior pole of parasite body, mid-nucleus to anterior (MA) $22.3 \pm 5.5 \mu \mathrm{m}(11.1-32.3 \mu \mathrm{m})$, mid-nucleus to posterior (MP) $7.0 \pm 3.7 \mu \mathrm{m}(3.6-17.3 \mu \mathrm{m})(\mathrm{n}=11)$, nuclear index $\mathrm{MP} / \mathrm{MA}=0.3 \pm 0.2(0.1-0.4)$.

Forming a mixed infection with Desseria harriottae sp. n. (above).

Type host: Harriotta raleighana Goode et Bean (Holocephali, Chimaeriformes, Rhinochimaeridae).

Type locality: Porcupine Seabight, Northeast Atlantic $49^{\circ} 49.9^{\prime} \mathrm{N}, 12^{\circ} 10.8^{\prime} \mathrm{W}$ (depth from $1631 \mathrm{~m}$ ).

Site of infection: Blood plasma of $H$. raleighana.

Prevalence: $1 / 1$ H. raleighana.

Specimens deposited: Hapantotype slide: in the collection of the Natural History Museum, London, UK (fish blood film with trypomastigotes of $T$. harriottae, Registration Number NHMUK 2011.7.16.1)

Ety mology: The species epithet refers to the host genus.
Remarks. Few flagellates have been described from the blood of deep sea fishes. Khan et al. (1992) recorded a cryptobiid from the Macrouridae, and trypanosomes in a member of the Squalidae and in Halosauropsis macrochir (Halosauridae). Of the trypanosomes, the first was in too poor condition to study accurately, but that from H. macrochir was illustrated by Khan et al. (1992). The drawings show finely granular, slender trypanosomes, with a distinct undulating membrane with around 8-12 undulations, and a clearly defined nucleus, kinetoplast and flagellum. The organisms also have a tendency to coil, but from the scale provided it can be estimated that their total body length is $\sim 160 \mu \mathrm{m}$, with a maximum body width of $\sim 7 \mu \mathrm{m}$. These trypanosomes from $H$. macrochir thus exceed enormously those found in the present study in body length ( $~ 30 \mu \mathrm{m}$ in the current study), though they match broadly in body width. Incidentally, it is interesting that no trypanosomes were located in $H$. macrochir in the current study.

When the trypanosomes found in the $H$. raleighana are compared with those recorded from other cartilaginous fishes generally (see Yeld and Smit 2006), there are no obvious matches in morphometric data. Thus, it is concluded that the trypanosome described here, forming a mixed parasitaemia with Desseria harriottae, is also a new species. Trypanosoma harriottae $\mathrm{sp}$. $\mathrm{n}$. is, therefore, only the second blood parasite to have been described from a cartilaginous fish within the subclass Holocephali.

\section{A reassessment of species within the genus Desseria Siddall, 1995}

While acknowledging difficulty in proving lack of erythrocytic merogony, Siddall (1995) created the genus Desseria for fish haemogregarines in which this process is apparently absent. Desseria myoxocephali (Fantham, Porter et Richardson, 1942) was named as the type species, with fishes of the genus Myoxocephalus, and the leech Malmiana scorpii (Malm), as the type hosts. A further 40 fish haemogregarines were also listed within the genus (Siddall 1995). However, re-examination of the literature reveals that some Desseria species were omitted from the original list and new Desseria species have been reported since the genus was established. Furthermore, while many species listed originally appear valid, some clearly belong to other genera, some are synonymous with other species, and others are likely invalid species. Since $D$. harriottae, named here, is a new species that can be added to Siddall's (1995) list, it was considered worthwhile to reassess species listed within the genus Desseria. Explanations, including reasons for change, appear in square brackets, with fish names updated, if appropriate, from Froese and Pauly (2011). Species removed from the list appear in bold typeface. 


\section{Species retained within the original list of the genus Desseria Siddall, 1995:}

1. Desseria acanthoclini (Laird, 1953) Siddall, 1995 in Acanthoclinus quadridactylus [probably Acanthoclinus littoreus (Forster)]

2. Desseria aeglefini (Henry, 1913) Siddall, 1995 (syn. Haemogregarina urophysis Fantham, Porter et Richardson, 1942) in Melanogrammus aeglefinus (L.), Pollachius virens (L.), Gadus morhua L., and Urophysis spp.

3. Desseria anarhichadis (Henry, 1912) Siddall, 1995 (syn. Haemogregarina anarrhichadis Henry, 1912) in Anarhichas lupus L.

4. Desseria brevoortiae (Saunders, 1964) Siddall, 1995 in Brevoortia tyrannus (Latrobe)

5. Desseria catostomi (Becker, 1962) Siddall, 1995 in Catostomus spp.

6. Desseria colisa (Mandal, Ray, Sarkar et Kahali, 1984) Siddall, 1995 in Colisa fasciata (Bloch et Schneider)

7. Desseria dakarensis (Léger et Léger, 1920) Siddall, 1995 in Diagramma mediterraneum [probably Plectorhinchus mediterraneus Guichenot]

8. Desseria dasyatis (Saunders, 1958) Siddall, 1995 in Dasyatis americana Hildebrand et Schroeder

9. Desseria esoci (Nawrotsky, 1914) Siddall, 1995 (syn. Desseria esocis (Nawrotsky, 1914) Siddall, 1995) in Esox spp. [the species epithet has been replaced - see BykhovskayaPavlovskaya et al. 1964]

10. Desseria gilbertiae (Mackerras et Mackerras, 1925) Siddall, 1995 (syn. Desseria gilbertia (Mackerras et Mackerras, 1925) Siddall, 1995) in Ellerkeldia spp. [the species epithet has been corrected - see Mackerras and Mackerras 1925]

11. Desseria heterodonti (von Prowazek, 1910) Siddall, 1995 in Heterodontus japonicus Maclay et Macleay

12. Desseria irkalukpiki (Laird, 1961) Siddall, 1995 in Salvelinus spp.

13. Desseria lepidosirensis (Jepps, 1927) Siddall, 1995 (syn. Haemogregarina bertoni Shouten, 1941) in Lepidosiren paradoxa Fitzsinger

14. Desseria leptocotti (Hill et Hendrickson, 1991) Siddall, 1995 (syn. Haemogregarina reolofsi Hill et Hendrickson, 1991) in Leptocottus armatus Girard and Sebastes melanops Girard

15. Desseria londoni (Yakimov et Kohl-Yakimov, 1912) Siddall, 1995 in Blennius trigloides [probably Paralipophrys trigloides (Valenciennes)]

16. Desseria mavori (Laird et Bullock, 1969) Siddall, 1995 in Macrozoarces americanus [probably Zoarces americanus (Bloch et Schneider)]

17. Desseria moringa (Pessoa et de Biasi, 1975) Siddall, 1995 in Gymnothorax moringa (Cuvier)

18. Desseria mugili (Carini, 1932) Siddall, 1995 in Mugil spp., Awaous ocellaris (Broussonet) and Stenogobius genivittatus (Valenciennes)

19. Desseria myoxocephali (Fantham, Porter et Richardson, 1942) Siddall, 1995 in Myoxocephalus spp. and Malmiana scorpii (Malm)
20. Desseria nili (Wenyon, 1909) Siddall, 1995 in Ophiocephalus obscurus [probably Parachanna obscura (Günther)]

21. Desseria ninakohlyakimovae (Yakimov, 1915) Siddall, 1995 (syns. Haemogregarina ninakohlyakimovae (Yakimov, 1915) Wenyon, 1926 emend. Levine, 1985; Leucocytogregarina ninae kohl-yakimovae Yakimov, 1915; Leucocytogregarina ninae kohl-yakimovi Yakimov, 1915; Hepatozoon ninae kohl-yakimoff (Yakimov, 1915) Shul'man, 1962 ) in Barbus spp. [the authority for H. ninae kohlyakimoff replaces that quoted by Siddall (1995), since S. S. Shul'man authored the relevant section in BykhovskayaPavlovskaya et al. 1962 - see Bykhovskaya-Pavlovskaya et al. 1964]

22. Desseria nototheniiae (Barber, Mills Westermann et Storez, 1987) Siddall, 1995 in Notothenia spp.

23. Desseria parasiluri (Zmeev, 1939) Siddall, 1995 in Parasilurus asotus [the authority for D. parasiluri replaces that quoted in Siddall (1995) - see Dogel and Akhmerov 1959; Parasilurus asotus is probably Silurus asotus L.]

24. Desseria rovignensis (Minchin et Woodcock, 1910) Siddall, 1995 in Trigla lineata [probably Trigloporus lastoviza (Bonnaterre)]

25. Desseria rubrimarensis (Saunders, 1960) Siddall, 1995 in Acanthurus spp., Chlorurus spp. and Scarus spp. [BUT retained only for the haemogregarine-like stages of this parasite, since other stages appear "Haemohormidium-like" - see Smit et al. 2006]

26. Desseria salvelini (Fantham, Porter et Richardson, 1942) Siddall, 1995 in Salvelinus fontinalis (Mitchill)

27. Desseria thyrsoideae (de Mello et Vales, 1936) Siddall, 1995 (syn. Desseria thyrosoideae (de Mello et Vales, 1936) Siddall, 1995) in Thyrosoidea macrurus Bleeker [the species epithet has been corrected - see de Mello and Vales 1936; Thyrosoidea macrurus is likely Strophidon sathete (Hamilton)]

28. Desseria tilapiae (Léger et Léger, 1914) Siddall, 1995 in Tilapia lata [possibly Tilapia lata camerunensis Lönnberg]

29. Desseria torpedinis (Neumann, 1909) Siddall, 1995 (syn Haemogregarina lobianci Kohl-Yakimov et Yakimov, 1912) in Torpedo spp.

30. Desseria turkestanica (Yakimov et Shokher, 1917) Siddall, 1995 in Silurus spp.

\section{Additional Desseria species omitted from the original list, or described subsequently:}

31. Desseria baueri (Becker, 1968) comb. n. (syns. Haemogregarina cotti Bauer, 1948; Haemogregarina baueri Becker, 1968; Desseria cotti (Brumpt et Lebailly, 1904) Siddall, 1995) in Cottus sibiricus Kessler [a freshwater fish haemogregarine different from the marine Haemogregarina cotti (below) - see Becker 1968]

32. Desseria harriottae in Harriotta raleighana Goode et Bean [this report]

33. Desseria marshalllairdi (Khan, Threlfall et Whitty, 1992) Smith, 1996 (syn. Haemogregarina marshallairdi Khan, Threlfall et Whitty, 1992) in Macrourus berglax Lacépède, Nezumia bairdi (Goode et Bean) and Halosauropsis macrochir (Günther) [see Khan et al. 1992, Smith 1996, this report] 
34. Desseria vltavensis (Lom, Kepr et Dyková, 1989) comb. n. (syn. Haemogregarina vltavensis Lom, Kepr et Dyková, 1989) in Perca fluviatilis L. [see Lom et al. 1989]

35. Desseria zei Smit et Davies, 2006 in Zeus capensis Valenciennes [see Smit and Davies 2006]

\section{Species removed from Siddall's (1995) list and returned to their original taxonomic status, allocated a different genus/species, or merged in synonymy:}

1. Haemogregarina (sensu lato) acipenseris Nawrotsky, 1914 (syns. Leucocytogregarina sp. Perekropov, 1928; Desseria acipenseri (Nawrotsky, 1914) Siddall, 1995) in Acipenser ruthenus L. [intraerythrocytic merogony present - see Lom and Dyková 1992]

2. Babesiosoma bettencourti Cruz et Davies, 1998 (syns. Haemogregarina bettencourti França, 1908; Desseria bettencourti (França, 1908) Siddall, 1995) in Anguilla anguilla (L.) [intraerythrocytic cruciform division present see Cruz and Davies 1998]

3. Haemogregarina (sensu lato) cotti Brumpt et Lebailly, 1904 (syn. Desseria cotti (Brumpt et Lebailly, 1904) Siddall, 1995) in Taurulus bubalis (Euphrasen) [intraerythrocytic division present - see Brumpt and Lebailly 1904]

4. Sphaerospora renicola Dyková et Lom, 1982 (syns. Haemogregarina cyprini Smirnova, 1971; Desseria cyprini (Smirnova, 1971) Siddall, 1995) in Cyprinus carpio carpio L. [illustrates myxozoan development - see Lom and Dyková 1992, Davies 1995, Dyková and Lom 2007]

5. Haemogregarina (sensu lato) bigemina Laveran et Mesnil, 1901 (syns. Haemogregarina fragilis Fantham, 1930; Desseria fragilis (Fantham, 1930) Siddall, 1995) in Parablennius cornutus (L.) [intraerythrocytic division present - see Smit et al. 2003]

6. Haemogregarina (sensu lato) platessae Lebailly, 1904 (syns. Haemogregarina flesi Lebailly, 1904; Haemogregarina laternae Lebailly, 1904; Haemogregarina bothi Lebailly, 1905; Haemogregarina achiri Saunders, 1955; Desseria platessae (Lebailly, 1904) Siddall, 1995; Desseria flesi (Lebailly, 1904) Siddall, 1995; Desseria laternae (Lebailly, 1904) Siddall, 1995; Desseria bothi (Lebailly, 1905) Siddall, 1995) in Pleuronectes platessa L. and many other members of the Pleuronectiformes [intraerythrocytic division present - see Davies et al. 2009]

\section{Species removed from the list and considered invalid:}

1. Desseria carpionis (Franchini et Siani, 1923) Siddall, 1995 in Cyprinus carpio carpio L. [considered a "spurious description" - see Lom and Dyková 1992]

2. Desseria gobionis (Franchini et Siani, 1923) Siddall, 1995 in Gobio gobio (L.) [considered a "spurious description" see Lom and Dyková 1992]

\section{DISCUSSION}

Given the relatively small sample size ( $\mathrm{n}=113$ fishes), the variety of haematozoans found in blood films from marine fishes captured at depth was surprising. Although the Cape Verde Islands smears appeared species-poor compared with the species-rich Porcupine Seabight samples, the former catches were generally at shallower depths and more material is needed from this region before any firm conclusions can be drawn. The variety of haematozoans found in Porcupine Seabight samples was greater than previously at this site (Davies and Merrett 2000), the most significant finds on this occasion being the haemogregarine (Desseria harriottae sp. n.) and trypanosome (Trypanosoma harriottae sp. n.) forming a mixed parasitaemia in Harriotta raleighana. Fishes such as this chimaera have fossil records dating back the Upper Devonian period (Smith and Heemstra 1995). It is interesting to speculate that the host-parasite relationship may also be an ancient one. Furthermore, as noted earlier, the Holocephali represent a group from which blood parasites had previously never been described (Davies and Johnston 2000) making the current finds unique.

Following reassessment of its species, the genus Desseria now contains 35 , rather than the original 41 species of Siddall (1995). Nine species were removed from the original list because they had been allocated different genera and or/species before, or since 1995, or merged in synonymy. Two more species were removed because they were considered invalid, and five species were added to the list, including D. harriottae. As acknowledged earlier, it is not ideal to base a genus characteristic on lack of intraerythrocytic merogony and further modifications to species listed within the genus Desseria will no doubt be necessary in future as life cycles are elucidated and molecular methods are applied. Unfortunately, in the case of the deep sea material parasitaemias were sparse and no other fish tissues were available for study, so that knowledge of development in these hosts was extremely limited. Furthermore, the rarity value of the material meant that none was spare for molecular typing.

Within current Porcupine Seabight samples, three species of haemogregarines in addition to $D$. harriottae were identified, including another species of Desseria (D. marshallairdi) and two of Haemogregarina (Haemogregarina bathysauri sp. n. and Haemogregarina michaeljohnstoni). Desseria marshalllairdi was tentatively recorded in the present study from Halosauropsis macrochir and it is remarkable that this organism apparently occurs in deep sea fishes on both sides of the Atlantic and in families that now include the Halosauridae as well as the Macrouridae (see Khan et al. 1992). Only one of the haemogregarines found in the current study had been observed previously in Porcupine Seabight samples (Davies and Merrett 2000), namely $\mathrm{H}$. michaeljohnstoni (syn. $\mathrm{H}$. johnstoni) from $\mathrm{Ca}$ taetyx laticeps. Conversely, an extracellular Desseria sp. found in Alepocephalus rostratus Risso captured in the Porcupine Seabight earlier (Davies and Merrett 2000) was not detected in any members of the Alepocephalidae examined during the current work.

Haemohormidium spp. are enigmatic organisms of uncertain identity, although an affinity with the microsporidians has been noted (see Davies et al. 2003, 2009). Khan et al. (1992) found these structures commonly among fishes 
of the northwest Atlantic and the same is true in fishes of the Porcupine Seabight, though less so of the Cape Verde Islands. These organisms, and the haemogregarines and trypanosome recorded above presumably have vectors for transmission between fishes, and Khan et al. (1992) and Davies and Merrett (2000) speculated what these might be. Haematophagous isopods and leeches likely transmit coastal marine fish haemogregarines (Davies and Smit 2001, Hayes et al. 2006), but neither of these ectopara- sites was found in the current study. Amphipods are abundant in the deep sea, scavenging widely on bait set on the abyssal floor to attract fish (Lampitt et al. 1983), but whether these crustaceans can act as vectors is unknown. Also, fish migration within the deep sea can be difficult to track, but some of the species recorded here may move up or down the slope during breeding and maturation (Merrett and Haedrich 1997), perhaps exposing them to the vectors necessary for haematozoan transmission.

\section{REFERENCES}

BeCKeR C.D. 1968: Haemogregarina baueri nom.n., a replacement for H. cotti Bauer, 1948 (Coccidia: Adeleina), preoccupied. J. Parasitol. 54: 167.

Brumpt E., Lebailly C. 1904: Description de quelques nouvelles espèces de trypanosomes et d'hémogrégaries parasites des téléostéens marins. C. R. Acad. Sci. Paris 139: 613-615.

Bykhovskaya-Pavlovskaya I.E., Gusev A.V., Dubinina M.N., Izyumova N.A., Smirnova T.S., Sokolovskaya I.L., Shtein G.A., Shul'man S.S., Epshtein V.M. 1964: Key to Parasites of Freshwater Fish of the U.S.S.R. [Translated from the 1962 Russian Version.] Israel Program for Scientific Translations, Jerusalem, 919 pp.

Cruz C., Davies A.J. 1998: Some observations on Babesiosoma bettencourti (França, 1908) n. comb. (syns. Haemogregarina bettencourti França, 1908; Desseria bettencourti Siddall, 1995) from eels, Anguilla anguilla L., in Portugal. J. Fish Dis. 21: 443-448.

Davies A.J. 1995: The biology of fish haemogregarines. Adv. Parasitol. 36: 117-203.

Davies A.J., Amado L.L., Cook R.T., Bianchini A., Eiras J.C. 2009: Potential environmental and host gender influences on prevalence of Haemogregarina platessae (Adeleorina: Haemogregarinidae) and suspected Haemohormidium terraenovae (incertae sedis) in Brazilian flounder from the Patos Lagoon Estuary, Southern Brazil. Folia Parasitol. 55: 161-170.

Davies A.J., Johnston M.R.L. 2000: The biology of some intraerythrocytic parasites of fishes, amphibians and reptiles. Adv. Parasitol. 45: 1-107.

Davies A.J., Merrett N.R. 1998: Presumptive viral erythrocytic necrosis in the benthopelagic fish Coryphaenoides (Nematonurus) armatus from the abyss west of Portugal. J. Mar. Biol. Assoc. U.K. 78: 1031-1034.

Davies A.J., Merrett N.R. 2000: Haemogregarines and other blood infections from deep demersal fish of the Porcupine Seabight, north-east Atlantic. J. Mar. Biol. Assoc. U.K. 80: 1095-1102.

Davies A.J., Reed C.C., Smit N.J. 2003: An unusual intraerythrocytic parasite of Parablennius cornutus from South Africa. J. Parasitol. 89: 913-917.

Davies A.J., Smit N.J. 2001: The life cycle of Haemogregarina bigemina (Adeleina: Haemogregarinidae) in South African hosts. Folia Parasitol. 48: 169-177.

de Mello I.F., Vales C. 1936: Haemogregarina thyrsoideae n. sp., parasite of the Indian eel Thyrsoidea macrurus Bleeker. Proc. Ind. Acad. Sci., Sec. B, 4: 403-404.

Dogel V.A., Akhmerov A.K. 1959: New species of parasitic protozoa of the Amur River. Ceskosl. Parasitol. 6: 15-25.

Dyкové I., Lom J. 2007: Histopathology of Protistan and Myxozoan Infections in Fishes. An Atlas. Academia Press, Prague, $219 \mathrm{pp}$.

Received 6 May 2011
Froese R., Pauly D. (Eds.) 2011: FishBase. World Wide Web electronic publication, www.fishbase.org, version 02/2011.

Hayes P.M., Smit N.J., Seddon A.M., Wertheim D., Davies A.J. 2006: A new fish haemogregarine from South Africa and its suspected dual transmission with trypanosomes by a marine leech. Folia Parasitol. 53: 241-244.

Khan R.A., Threlfall W., Whitty W.S. 1992: Hematozoa of deep-sea demersal fish of the Northwest Atlantic Ocean. Can. J. Zool. 70: 1926-1933.

Lampitt R.S., Merrett N.R., Thurston M.H. 1983: Inter-relations of necrophagous amphipods, a fish predator, and tidal currents in the deep sea. Mar. Biol. 74: 73-78.

Lom J., Dyкоvé I. 1992: Protozoan Parasites of Fishes. Developments in Aquaculture and Fisheries Science, Vol. 26. Elsevier, Amsterdam, 315 pp.

Lom J., Kepr T., Dyкová I. 1989: Haemogregarina vltavensis n. sp. from perch (Perca fluviatilis) in Czechoslovakia. Syst. Parasitol. 13: 193-196.

Mackerras M.J. 1961: The haematozoa of Australian reptiles. Aus. J. Zool. 9: 61-122.

Mackerras I.M., Mackerras M.J. 1925: The haematozoa of Australian marine teleostei. Proc. Linn. Soc. N.S.W. 50: 359366.

Merrett N.R., Haedrich R.L. 1997. Deep-sea Demersal Fish and Fisheries. Chapman and Hall, London, 282 pp.

Siddall M.E. 1995: Phylogeny of adeleid blood parasites with a partial systematic revision of the haemogregarine complex. J. Eukaryot. Microbiol. 42: 116-125.

Smit N.J., Davies A.J. 2006: Desseria zei sp. nov. (Adeleorina: Haemogregarinidae) infecting Zeus capensis from deep waters off the south and west coasts of South Africa. J. Mar. Biol. Assoc. U.K. 86: 1477-1480.

Smit N.J., Grutter A.S., Adlard R.D., Davies A.J. 2006: Hematozoa of teleosts from Lizard Island, Australia, with some comments on their possible mode of transmission and the description of a new hemogregarine species. J. Parasitol. 92: 778-788.

Smit N.J., Van As J.G., Davies A.J. 2003: Taxonomic re-evaluation of the South African fish haemogregarine, Desseria fragilis. J. Parasitol. 89: 151-153.

Smith M.M., Heemstra P.C. 1995: Smith's Sea Fishes. Southern Book Publishers, Johannesburg, 1047 pp.

Sмiтн T.G. 1996: The genus Hepatozoon (Apicomplexa: Adeleina). J. Parasitol. 82: 565-585.

Yeld E.M., Smit N.J. 2006: A new species of Trypanosoma (Kinetoplastida: Trypanosomatidae) infecting catsharks from South Africa. J. Mar. Biol. Assoc. U.K. 86: 829-833. 